\title{
Determinants of Households' Food Security in Akure South Local Government Area of Ondo State, Nigeria
}

\author{
Oluwakemi ODUNTAN ${ }^{1 *}$ and Ayodeji O. AKINRO ${ }^{2}$ \\ Department of Agricultural and Resource Economics, Federal University of Technology, PMB 704, Akure, \\ Ondo State, Nigeria
}

\begin{abstract}
The study examined the determinants of households' food security in Akure South Local Government Area of Ondo State, Nigeria. The study used a multi-stage sampling procedure to select eighty respondents with the aid of a structured questionnaire. Data were collected randomly from four communities and analyzed using a combination of descriptive statistics, food security index and probit regression model. The results revealed that food secure households had an average daily per capita calorie consumption of $3854.46 \mathrm{Kcal}$ while the households that were food insecure had an average daily per capita calorie consumption of $1564.3 \mathrm{Kcal}$. The results of probit regression revealed that, household size, level of education, household head's income and number of income earners were significant determinants of food security among households. Level of education, household head's income and number of income earners influenced food security positively while household size affected it negatively. Based on the findings of the study, it was therefore recommended that households should diversify their sources of income and register with cooperative societies which may be necessary for them to access funds and also there should be limit in population size through integrated health and education services.
\end{abstract}

Keywords: Determinants, Food Security, Households, Probit Model

DOI: $10.7176 / J E S D / 12-22-04$

Publication date: November $30^{\text {th }} 2021$

\section{Introduction}

Food Security is a growing concern worldwide. According to the 2010 state of food insecurity report of the United Nation's Food and Agriculture Organization (FAO), nearly one billion people are estimated to be under-nourished, of which developing nations account for $98 \%$ (FAO 2010). In particular, since the 2008 food price crisis, food security has once again become a key issue for many poor countries and a global problem as well. Food security is indispensable prerequisite for the survival of mankind and his economic activities. Making the world free from hunger, malnutrition and poverty and providing the people basic needs is the greatest challenge especially for people living in less developing countries. Achieving food security has been a major challenge and it has been given as the first priority in achieving most fundamental human right in all developing countries. The current global food crisis emerging from soaring prices of staples and depletion of food stocks and lack of access to food by poor people in many developing (Adewumi, 2011).

Food security has been defined as a situation when all people, at all times, have access to sufficient, safe and nutritious food to meet dietary needs and food preference for an active and healthy life (FAO, 2009). It is the "access by all people at all times to safe and nutritious food needed to maintain a healthy and active life" (FAO, 2000; Akintayo 2011). Food security, according to the United State Department of Agriculture (2012), includes at a minimum; (i) the ready availability of nutritionally adequate and safe foods, (ii) assured ability to acquire acceptable foods in socially acceptable ways (that is without resorting to emergency food supplies, scavenging, stealing, or other coping strategies).

Nigeria is blessed with abundant natural and human resources, but despite its significant natural resources, majority of her citizens are living in hunger and below the poverty line. Among the developmental problems facing Nigeria, food insecurity rank topmost. The level of food insecurity has continued to rise steadily since $1980 \mathrm{~s}$. It rose from about 18 percent in 1986 to about 41 percent in 2004 and 48 percent in 2012 (Sanusi et al., 2014). According to World Development Indicator (WDI) (2015), an estimated $60 \%$ of Nigerians live on less than US $\$ 1.25$ per day. Nigeria was ranked $91^{\text {st }}$ out of a total of 187 countries on the 2012 UNDP Human Development Index. Malnutrition and hunger have been ravaging most developing countries and affecting their productive capacity. Classifying Nigeria as one of the poorest countries, testifies to her failure to achieve the development policy as well as national food security.

The Nigerian food security situation is characterized by inadequate domestic food supplies and increasing food imports (Akoroda, 2010). The estimated 3.7 percent food production growth rate cannot keep pace with the 6.5 percent food demand fuelled by a high rate of population increase, moderately rapid income growth, and relatively high elasticities of expenditure for food (Egwuda, 2014). Given the fact that $75 \%$ of the world's hungry people live in the rural areas, the fight to eliminate hunger and reach the other Millenium Development Goals will be won or lost in rural areas (Alabi et al., 2011). However, an understanding of the situation of food security and poverty at household level and how people cope with food insecurity by adopting different mechanisms is very 
important. Such understanding allows policy makers to better plan and takes actions that address the specific problems, as well as development of potentials of the different population segments.

\section{Methodology}

\subsection{Study Area}

The study was carried out in Akure South Local Government Area of Ondo State, Nigeria. The State is situated entirely within the tropics. It is located between longitude $4^{\circ} 20^{\prime}$ and $6^{\circ} 5^{\prime}$ East of the Greenwich Meridian and latitude $5^{\circ} 45^{\prime}$ and $7^{\circ} 52^{\prime}$ North of the equator. Akure South is located within the tropical rainforest zone with an estimated land mass of about 1,514 sq. kilometres in area. And it is bounded by Ijesa on the western side, Ondo on the southern side, Benin on the eastern side and Ado on the northern side (Adejuyigbe, 1992). The local government comprise of more than 20 villages. The major occupation of the villagers is farming. Some of the villagers are also involved in hunting, bricklaying, bicycle repairing as their secondary occupation. The major language spoken by the people is local Yoruba dialect which is also interspersed with the dialects of some ethnic groups (Ibira, Igede) dwelling in the villages. The major religions of the people in these villages are Christianity, Islam and traditional religion (Ogunleye et al. 2007).

\subsection{Sampling Procedure and Data Collection}

Primary data were collected for this study. The data were collected from the respondents with the aid of a structured questionnaire. Multi-stage sampling procedure was used in selecting the respondents. In the first stage Akure South Local Government Area was purposively selected from the (18) Local Government in Ondo State because of the high population size (Oyinloye and Kufoniyi, 2011). The second stage involved random selection of four communities from the local government area namely: Aule, Ipinsa, Ondo road, and Oke-aro while the last stage involved random selection of (20) households from each of the selected communities and in all, total number of (80) households were sampled.

\subsection{Data Analysis}

Data collected were analyzed with the use of descriptive statistics, food security index and probit regression model. The descriptive statistics such as frequency distribution, mean, and percentages were used to analyze the socioeconomic characteristics of the respondents and other average statistics.

\subsubsection{Food Security Index}

To measure household food security, a food security index was constructed. This involves two steps: identification and aggregation. Identification is the process of defining a minimum level of nutrition necessary to maintain healthy living - the "food security line" for the population under study, below, which households will be classified as food-insecure. Aggregation on the other hand derived food security statistics for the households. The FAO recommended minimum daily energy requirement per adult equivalent is $2260 \mathrm{kcal}$; therefore this values define the food security lines for the study. Households which are below the food security line were classified as foodinsecure households while those households that are above were classified as food secure households. Aggregation involves the estimation of the daily per capita calorie supply of household size adjusted for adult equivalent using the consumption factor for age - sex. The nutrients content of both produced and purchased food items were used to derive calories availability.

A daily recommended level of $2260 \mathrm{kcal}$ per capita per day defined the security line that was used for this study (NBS, 2010).

Food Security Index $\mathrm{Z}=\frac{\text { Household's daily per capita calories availability }(A)}{\text { Household's daily per } \text { capita } \text { calorie requirement }(I)}$

Based on Z, two food security measures were calculated:

When $\mathrm{Zi}>1=$ Food secure ith household

$\mathrm{Zi}<1=$ Food insecure ith household

For the purpose of this study, a household was defined as a group of people living together and eating from the same pot.

2.3.2 Probit Regression Model

Probit regression model was employed in determining the factors influencing the food security status of households based on the household food security index $(\mathrm{Zi})$. The explicit form of the model is expressed as:

$\mathrm{Z}_{\mathrm{i}}=\beta \mathrm{Xji}+\mathrm{U}$

$Z_{i}=$ Household food security status (food secure households $=1$, food insecure households $=0$ )

$\mathrm{X}_{\mathrm{j}}=$ vector of explanatory variables

$\mathrm{U}=$ Error term

$\mathrm{B}=$ Vector of the parameter estimates

$\mathrm{X}_{\mathrm{j}}=$ are explanatory variables and are defined as follows:

$\mathrm{X}_{1}=$ Sex of household head $($ Male $=1 ;$ Female $=0)$ 
$\mathrm{X}_{2}=$ Household size (Number)

$\mathrm{X}_{3}=$ Marital status of household head (married/living together $=1$; otherwise $=0$ )

$\mathrm{X}_{4}=$ Age of household head (Years)

$\mathrm{X}_{5}=$ Income of household head (Naira)

$\mathrm{X}_{6}=$ Access to credit (Access $=1$; No access $=0$ )

$\mathrm{X}_{7}=$ Level of education of household head (Years)

$\mathrm{X}_{8}=$ Employment status of household head $($ employed $=1$; not employed $=0)$

$\mathrm{X}_{9}=$ The number of income earners.

\section{Results and Discussion}

\subsection{Socio Economic Characteristics of Respondents}

The results of the socio-economic characteristics of households in the study area in Table 1 showed that $72.5 \%$ of the respondents are male, while $27.5 \%$ of the respondents are female. The Table also showed that the mean age of the respondents was 47years which implies that majority of them were within the economically active age. Majority (75.4\%) of the respondents were married. This implies that majority of the respondents have families to cater for. Majority of the respondents $(87.2 \%)$ had one form of formal education or the other. Improved education and high literacy level is an important tool for a household head to react smartly to declining disposable income. This is supported by Adepoju and Adejare (2013) that food security is improved by the literacy status of the household head. The high level of literacy among the respondents could translate to their attainment of food security. Furthermore, the Table indicated that most (58.8\%) of the respondents had household size of 1-5 persons. This implies that the large household size suggests that there is abundant supply of family labour in the study area, which can be harnessed for increased agricultural production. However, large household size could increase the level of food insecurity among the respondents as large family size affects food availability per person in the family (Adebayo, 2012). The Table also showed that few $(11.2 \%)$ of the respondents engaged in farming as primary occupation, $31.3 \%$ of the respondents engaged in farming as secondary occupation while $57.5 \%$ of the respondents engaged in other occupation aside farming. This implies that majority of the respondents were involved in non-farming activities as their major occupation.

Table 1: Socio-Economic Characteristics of Respondents

\begin{tabular}{|c|c|c|}
\hline Variable & Frequency & Percentage \\
\hline \multicolumn{3}{|l|}{ Sex } \\
\hline Male & 58 & 72.5 \\
\hline Female & 22 & 27.5 \\
\hline Total & 80 & 100.0 \\
\hline \multicolumn{3}{|l|}{ Age } \\
\hline $31-40$ & 4 & 5.0 \\
\hline $41-50$ & 25 & 31.2 \\
\hline $51-60$ & 31 & 38.8 \\
\hline $61-70$ & 16 & 20.0 \\
\hline $71-80$ & 4 & 5.0 \\
\hline Total & 80 & 100.0 \\
\hline \multicolumn{3}{|l|}{ Marital status } \\
\hline Single & 5 & 6.3 \\
\hline Married & 62 & 75.4 \\
\hline Divorced & 5 & 6.3 \\
\hline Widowed & 8 & 10.0 \\
\hline Total & 80 & 100.0 \\
\hline \multicolumn{3}{|l|}{ Educational level } \\
\hline No formal Education & 11 & 13.8 \\
\hline Primary School Education & 13 & 16.1 \\
\hline Secondary School Education & 19 & 23.8 \\
\hline Tertiary Education & 30 & 37.5 \\
\hline Post tertiary Education & 7 & 8.8 \\
\hline Total & 80 & 100.0 \\
\hline \multicolumn{3}{|l|}{ Household size } \\
\hline$\leq 5$ & 47 & 58.8 \\
\hline $6-10$ & 33 & 41.2 \\
\hline Total & 80 & 100.0 \\
\hline \multicolumn{3}{|l|}{ Major occupation } \\
\hline Farming as primary & 9 & 11.2 \\
\hline
\end{tabular}




\begin{tabular}{lll}
\hline & & \\
\hline Farming as secondary & 25 & 31.3 \\
Other occupation & 46 & 57.5 \\
Total & 80 & 100.0 \\
\hline
\end{tabular}

Source: Field Survey, 2018.

\subsection{Monthly Expenditure of Respondents}

The results of the monthly expenditure of households in the study area in Table 2 showed that $15 \%$ of the respondents spent below $\$ 20,000$ per month, 32.5\% spent between $\$ 20,000$ and $\$ 30,000,20 \%$ spent between $\$ 30,000$ and $\$ 40,000,15 \%$ spent between $\$ 40,000$ and $\$ 50,000,5 \%$ spent between $\$ 50,000$ and $\$ 60,000,5 \%$ spent between $\$ 60,000$ and $\$ 70,000,1.3 \%$ spent between $\$ 70,000$ and $\$ 80,000$, about $1.3 \%$ spent between $\$ 80,000$ and $\$ 90,000$, while $5 \%$ of respondents spent above $\$ 100,000$ per month. Since most $(32.5 \%)$ of the respondents had low purchasing power therefore, it leads to reduction in calorie intake.

Table 2: Distribution of Respondents by Monthly Expenditure

\begin{tabular}{lcc}
\hline Monthly expenditure & Frequency & Percentage \\
\hline Below 20,000 & 12 & 15.0 \\
$20,000-30,000$ & 26 & 32.5 \\
$30,000-40,000$ & 16 & 20.0 \\
$40,000-50,000$ & 12 & 15.0 \\
$50,000-60,000$ & 4 & 5.0 \\
$60,000-70,000$ & 4 & 5.0 \\
$70,000-80,000$ & 1 & 1.3 \\
$80,000-90,000$ & 1 & 1.3 \\
100,000 and above & 4 & 5.0 \\
Total & 80 & 100.0 \\
\hline
\end{tabular}

Source Field survey, 2018

\subsection{Monthly Income of Respondents}

The results of the monthly income of households in the study area in Table 3 showed that $40 \%$ of respondents received monthly income below $\$ 100,000$ while $35 \%$ received monthly income between $\$ 100,000$ and $\$ 150,000$, $8.8 \%$ received monthly income between $\$ 150,000$ and $\$ 200,000,6.3 \%$ received monthly income between $\$ 200,000$ and $\$ 250,000,5 \%$ received monthly income between $\$ 250,000$ and $\$ 300,000$, and $5 \%$ of respondents received monthly income above $\$ 350,000$. Income has been a vital tool in assessing human well-being (Aruwajoye and Ajibefun, 2013). Income determines the quantity and quality of food that can be accessed by a household considering the household size. High income could enhance the purchasing power of households and increase calorie intake and food security. Conversely, low income could be detrimental to food security as households will be unable to purchase food items.

Table 3: Distribution of Respondents by Monthly Income

\begin{tabular}{lll}
\hline Monthly income & Frequency & Percentage \\
\hline Below 100,000 & 32 & 40.0 \\
$100,000-150,000$ & 28 & 35.0 \\
$150,000-200,000$ & 7 & 8.8 \\
$200,000-250,000$ & 5 & 6.3 \\
$250,000-300,000$ & 4 & 5.0 \\
350,000 and above & 4 & 5.0 \\
Total & 80 & 100.0 \\
\hline
\end{tabular}

Source Field survey, 2018

\subsection{Analysis of Food Security Status of Households}

The food security status of the respondents was estimated using the Food Security Index. The index was used to classify the respondents into food secure and food insecure households. Table 4 presents the summary statistics and food security indices among the sampled households. Based on the daily calories (R) of $2260 \mathrm{kcal}$, it was observed that $40 \%$ of the households were food secure while $60 \%$ were food insecure.

The results further showed that the average per capita calorie intake in the area was $2709.38 \mathrm{kcal}$. This was a bit higher than the national average of $2700 \mathrm{kcal}$. The average calories intake of food secure households was $3854.46 \mathrm{kcal}$, which is far higher than the national average of $2700 \mathrm{kcal}$. Also, the calorie intake of the food insecure households was $1564.3 \mathrm{kcal}$, which is far lower than the national average. The households in the study area could be regarded as food insecure given the fact that $60 \%$ of the population were not able to meet the recommended calorie intake of $2260 \mathrm{kcal}$ per capita per day. Food security index (FSI) for the food secure 
households in the study area was calculated to be 1.71 while it was 0.69 for the food insecure households.

Table 4: Summary of Food Security Index (FSI) for Households in the Study Area

\begin{tabular}{lll}
\hline Variables & Households & \\
\hline Food Security Indices & $\begin{array}{l}\text { Food Secure } \\
\text { Intake(I) 2260K }\end{array}$ & Food Insecure \\
Recommended/Capita Calorie & 33 & 47 \\
No of household & 40 & 60 \\
Percentage of household & 3.38 & 6.08 \\
Mean of Household size (adult equivalent) & 3854.46 & 1564.3 \\
Mean of Household Daily per capita calories consumption (kcal) & 1.71 & 0.69 \\
Food Security Index & & \\
\hline
\end{tabular}

Source: Source Field survey, 2018

\subsection{Determinants of the Food Security Status of Households}

The results of the determinants of food security among households in the study area are presented in Table 5. The determinants of food security status of households was analyzed using probit regression model. The results revealed that household size, level of education, household head's income and numbers of income earners in the household were significant at $5 \%$. The coefficient of household size had a negative effect on food security status and statistically significant at 5\%. This implies that the higher the household size, the lower the probability household being food secured. This is because an increase in household size tends to increase the quantity of food consumed in a household. This result corroborates with the findings of Omonona and Agoi (2007), Oni and Fashogbon (2013), Adepoju and Adejare (2013) and Amurtiya (2015) who found that an increase in household size by one member increased the chance of the household becoming food insecure by indirectly reducing income per head.

Level of education had a positive coefficient and was significant at $5 \%$. This implies that household heads that are educated are more likely to be food secure than uneducated household heads. This is expected since the level of education should positively affect income earning capacity and level of managing household's food resources.

The result from Table 5 also revealed that coefficient of household head's income of respondents is significant at $5 \%$ and had a positive effect on household food security status. This indicates that the higher the income of household's head, the higher the probability of household being food secured. An increase in household income improves household food security because generally more food can be produced or purchased. Household income is the most significant determinant for household food security, with regards to food accessibility. The findings are similar to those of Bashir et al. (2012), who found a positive relationship between household income and household food security. Low income household are most likely to experience less food security than middle income households (Jacobs, 2009).

The results further revealed that coefficient of number of income earners was significant at $5 \%$ and had a positive effect on households' food security status. This indicates that the higher the number of income earners in the household, the higher the probability of household being food secured.

Table 5: Probit Model Estimation of Factors Affecting Household's Food Security Status

\begin{tabular}{llll}
\hline Variable & Coefficient & Standard error & P-value \\
\hline Sex & .562 & .579 & 0.332 \\
Age & .006 & .016 & 0.726 \\
Marital status & .408 & .412 & 0.322 \\
Household size & $-.311^{* *}$ & .128 & 0.015 \\
Educational level & $.000^{* *}$ & .000 & 0.000 \\
Occupation & .187 & .160 & 0.242 \\
Income earners & $1.336^{* *}$ & .443 & 0.003 \\
Access to credit & -.751 & .541 & 0.165 \\
Head income & $.0004^{* *}$ & .0002 & 0.033 \\
\hline Source: Field Survey & $\mathbf{2 0 1 8}$ & &
\end{tabular}

Source: Field Survey, 2018

Note: $* *=\mathbf{5} \%$ level of significance 


\section{Conclusion and Recommendations}

The study was carried out to examine the determinants of households' food security in Akure South Local Government area of Ondo State, Nigeria. The findings from this study has shown that the proportion of food insecure households $(60 \%)$ was higher than the food secure $(40 \%)$ households. Majority of the respondents were involved in non-farming activities as their major occupation. The food insecure households were found to have higher household size than the food secure households. From this, it is possible to conclude that households with greater household size are more likely to be food insecure as compared with households with smaller household size. On the other hand, the food secure households had relatively greater averages on income level and educational level of the head than food insecure households. The results revealed that household size, level of education, household head's income and number of income earners were significant determinants of food security status of households in the study area. In general, in order to achieve the households' food security, strategies should be designed in a way that would focus on and address the identified determinants as well as other factors that are useful to achieve household food security. It is therefore recommended that households should be educated on the need to diversify their source of income from agriculture. This will ensure regular incomes for the households. Enlightenment programs on health and birth control measures should be introduced to the households so as to educate them on the need to adopt modern family planning techniques and limit their family size.

\section{References}

Adebayo, O.O (2012). Effects of Family Size on Household Food Security in Osun State, Nigeria. Asian Journal of Agriculture and Rural Development, 2(2): 136-141.

Adejuyigbe, O. (1992). Territorial Limits of Akure land; Oyemekun Festival Lecture 1992, Ofamco Press Limited, Akure.

Adepoju, A.O. and Adejare, K.A. (2013). Food Insecurity Status of Rural Households during the Post Planting Season in Nigeria. Department of Agricultural Economics, University of Ibadan, Oyo State, Nigeria. Invited Paper Presented at the $4^{\text {th }}$ International Conference of the African Association of Agricultural Economists, September 22-25, Hammamet, Tunisia.

Adewumi, O.I. (2011). Non-Farm Activities and Poverty among Rural Farm Households in Yewa Division of Ogun State, Nigeria. Journal of Social Science 26(3): 217-224.

Akintayo, I. (2011). Increasing Rice Productivity and Strengthening Food Security through New Rice for Africa (NERICA). In: P.Chuhanpole and M.Angwafo, eds. Yes Africa Can; Success Stories from a Dynamic Continent Washington D.C. The World Bank, 253-267.

Akoroda, M.O. (2010). The Best Seeds of the Best Varieties: A Basis for Nigeria's Food Security. An Inaugural lecture Delivered at the University of Ibadan $22^{\text {nd }}$ of April. Ibadan University Press.

Alabi, O.J., Kumar, P. L. and Naidu, R.A. (2011). Cassava Mosaic Disease: A Curse to Food Security in SubSaharan Africa. Online. Apsnet Features.doi:10.1094/ApsnetFeature-2011-0701.

Amurtiya, M. (2015). Effect of Livelihood Income Activities on Food Security Status of Rural Farming Households in Yola South Local Government Area. M.Sc Thesis, Department of Agricultural Economics and Extension, Modibbo Adamawa University of Technology, Yola. https: //www.Researchgate.net/publication/285584404.

Aruwajoye, A.S. and Ajibefun, I.A. (2013). Assessment of Livelihood Strategies among Households in Forest Reserve Communities in Ondo State, Nigeria. International Journal of Scientific and Engineering Research, 4(7): ISSN 2229-5518.

Bashir, M. k. and Schilizzi, S. (2013). The Determinants of Rural Household Food Security: A Comparative Analysis of Africa and Asia Studies. Journal of the Science of Food and Agriculture. 93 (6): 251-258.

Bashir, M. k., Schilizzi, S. and Pandit, R. (2012). The Determinants of Rural Household Food Security in the Punjab, Pakistan: An Econometric Analysis, Working Paper 1203, School of Agricultural and Resource Economics, University of Western Australia, Crawley, Australia.

Egwuda, (2014). Food Security and Productivity of Urban Food Crop Farming Households in Southern Nigeria. ISSN 2291-4471 E-ISSN 2291 44. Published by Science and Education Centre of North America. 2(3): 0112.

Food and Agriculture Organization (FAO) (2010). Food Security; Concept and Measurement In: Food Security: The Science, Sociology and Economics of Food Production and Access to Food.

FAO (2009). The State of Food Insecurity in the World. Food and Agriculture Organization of the United Nations. Viale delle Terme di Caracalla, 00153 Rome, Italy.

Food and Agriculture Organization (FAO) (2000). Global Forest Resources Assessment. Main Report. FAO Forestry Paper No. 140. http://www.ftp.fao.org/docrep/fao/003/yo900e/

Jacob, F.T. (2009). The Status of Household Food Security Targets in South Africa. Agrekon. Agricultural Economics Research, Policy and Practice in Southern Africa, 48(4): 410-433. 
National Bureau of Statistics (NBS) (2010). Federal Ministry of Agriculture and Rural Development Collaborative Survey on National Agriculture Sample Survey (NASS), Draft Report.

Ogunleye, K. Y., Yekinni, O. T. and Adebo, A. A. (2007). Farmers' Children involvement in Cassava Production in Akure South Local Government Area of Ondo State, Nigeria. Agrosearch, 9(1): 61-71.

Omonona, B.T. and Agoi, G.A. (2007). An Analysis of Food Security Situation among Nigerian Urban Households: Evidence from Lagos State, Nigeria. Department of Agricultural Economics, University of Ibadan, Ibadan, Nigeria. Journal of European Agriculture, 8(2).

Oni, O.A. and Fashogbon, A.E. (2013). Food poverty and Livelihood Issues in Rural Nigeria. African Journal of Agricultural and Resource Economics, 8(2): 108-135.

Oyinloye, M and Kufoniyi, O (2011). Analysis of Landuse/ Landcover Change and Urban Expansion in Akure, Nigeria. Journal of Innovative Research in Engineering and Sciences, 234-248.

Sanusi R. A., Adebukola, B. C. and Oyindamola, Y. B. (2014). Measuring Household Food Insecurity in Selected Local Government Areas of Lagos and Ibadan, Nigeria. $\quad$ Pakistan Journal of Nutrition 5 (1): 6267.

USDA, (2012). United States Department of Agriculture, National Agricultural Statistics Service. https://www.nass.usda.gov/publications/AgCensus/2012/.

WDI, (2015). World Development Indicators. Retrieved from: https://data.worldbank.org/products/wdi (Accessed on 16th June, 2019). 